\title{
Material Aspects Pertaining to Hydrogen Production from Aluminum: Opinion
}

ISSN: 2576-8840

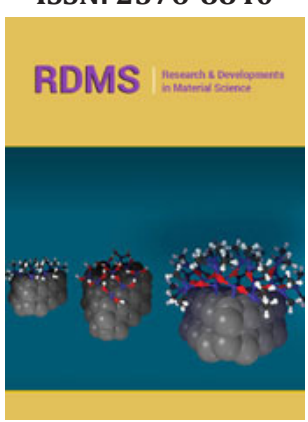

*Corresponding author: SP du Preez and Bessarabov DG, HySA Infrastructure, Faculty of Engineering, North-West University (NWU), Private Bag X6001, Potchefstroom 2520, South Africa

Submission: 侮 October 07, 2019

Published: 眥 October 15, 2019

Volume 12 - Issue 1

How to cite this article: SP du Preez, Bessarabov DG. Material Aspects Pertaining to Hydrogen Production from Aluminum: Opinion. Res Dev Material Sci. 12(1). RDMS.000778.2019.

DOI: 10.31031/RDMS.2019.12.000778

Copyright@ SP du Preez and Bessarabov DG, This article is distributed under the terms of the Creative Commons Attribution 4.0 International License, which permits unrestricted use and redistribution provided that the original author and source are credited.

\author{
SP du Preez* and Bessarabov DG* \\ HySA, Faculty of Engineering, North-West University (NWU), South Africa
}

\section{Opinion}

\section{Background}

The use of lightweight metals as hydrolyzing materials for hydrogen $\left(\mathrm{H}_{2}\right)$ generation has attracted much attention in recent years. This is clearly evident when one considers the continuous stream of publications being made available in the public peer-reviewed domain on the subject. Metal-based hydrolyzing materials are combined with water, under certain conditions, to allow the hydrolysis reaction, yielding high-purity $\mathrm{H}_{2}$ on demand. Of the lightweight metals investigated, aluminum (Al) has shown significant potential as it is lightweight, relatively inexpensive, and abundant.

\section{Reaction mechanisms}

The complete hydrolysis of Al yields $1.36 \mathrm{~L} \mathrm{H}_{2}$ per g Al under standard atmospheric conditions, according to the following reactions:

$$
\begin{aligned}
& 2 \mathrm{Al}+4 \mathrm{H}_{2} \mathrm{O}=2 \mathrm{AlO}(\mathrm{OH})+3 \mathrm{H}_{2} \\
& 2 \mathrm{Al}+6 \mathrm{H}_{2} \mathrm{O}=2 \mathrm{Al}(\mathrm{OH})_{3}+3 \mathrm{H}_{2}
\end{aligned}
$$

However, the hydrolysis of $\mathrm{Al}$ is prevented by a thin, coherent oxide layer on the surface of $\mathrm{Al}$, which prevents contact between the underlying metallic $\mathrm{Al}$ and water. This oxide layer is generally removed via the following routes: (i) exposure to solution of extreme $\mathrm{pH}$, ii) amalgamation with mercury/gallium, iii) thermal homogenization with certain metals (typically with metals with melting points below that of $\mathrm{Al}$ ), and iv) mechanochemical processing with water soluble salts, metal oxides and/or certain metals (e.g., gallium, zinc, tin, indium, and/or bismuth). Of these methods, it is the mechanochemical processing of $\mathrm{Al}$, which does not require the use of corrosive liquids and expensive/toxic elements, that appears most favorable. Advantages of its application include user/environmental friendliness and relatively low fabrication costs.

\section{Mechanochemically processed Al}

HySA Infrastructure (South Africa) has undertaken the fabrication of mechano-chemically processed $\mathrm{Al}$ composites using various activation compounds: bismuth, tin, and/or indium. These composites are highly reactive towards neutral $\mathrm{pH}$ water of various qualities (e.g., tap, filtered, deionized) [1-5]. Mechanochemical processing facilitates particle size reduction of the composite particles and the distribution of activation compounds throughout Al particles. When exposed to water, a large surface area and numerous microgalvanic cells between anodic $\mathrm{Al}$ and cathodic activation compounds affords these composites with high hydrolysis activity-yields of $>99 \% \mathrm{H}_{2}$ are achieved. Figure 1 illustrates the change in morphology of $\mathrm{Al}$ before and after processing.

The $\mathrm{H}_{2}$ generated from the hydrolysis of mechanochemically processed Al may be combined with proton exchange membrane fuel cells (PEMFCs) to convert the chemical energy of $\mathrm{H}_{2}$ into an electrical current. Because of the high purity of the generated hydrogen (more specifically, the absence of platinum-catalyst-poisoning carbon monoxide), its direct application in PEMFCs is acceptable without concern for catalyst degradation. The complete 
hydrolysis of $1 \mathrm{~kg}$ of $\mathrm{Al}$ may generate the energy equivalent of approximately $4.4 \mathrm{kWh}$ worth of $\mathrm{H}_{2}$-approximately $50-60 \%$ of which may be converted to electrical energy (depending on the efficiency of the relevant PEMFC) [6,7]. A possible real-world application includes refueling of PEMFC-powered unmanned aerial vehicles (UAVs) in the field. A 16kg battery-powered UAV has an operational capacity of $5 \mathrm{~h}$, whereas a similar PEMFC powered system consuming gaseous or liquid $\mathrm{H}_{2}$ can operate for 24 to $48 \mathrm{~h}$
[8]. A recent report by the US Army states the following: "The U.S. Army Research Laboratory plans to license its discovery of a nanogalvanic aluminum powder for $\mathrm{H}_{2}$ generation" [7]. The reasoning behind this is likely due to the low noise emissions of fuel cells, allowing stealthier operations. In addition to this, the relatively easy heat management of such a system can afford vehicles with low infrared signatures, when compared to traditional internal combustion engines used in military vehicles.

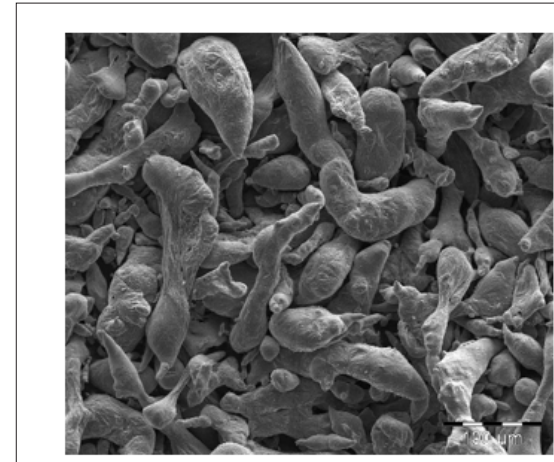

(a)

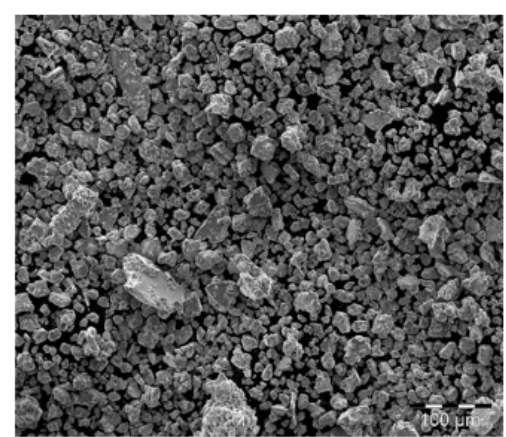

(b)

Figure 1: Field emission scanning electron microscopy images of Al particles: (a) before and (b) after mechanochemical processing using bismuth, tin, and/or indium as activation compounds.

\section{Challenges}

However, it is likely that suitable high-capacity reactor designs have yet to be realized as the hydrolysis of $\mathrm{Al}$ releases an appreciable amount of heat, which has a significant effect on the hydrolysis reaction kinetics. Al's hydrolysis is significantly accelerated by in-situ generated reaction heat and it may cause operational complications. In addition to this, hydrolysis products $(\mathrm{AlO}(\mathrm{OH})$ and/or $\mathrm{Al}(\mathrm{OH})_{3}$ ) precipitate as a gel-like substances that may result is reactor complications, such as blockages.

Considering the energy required to convert $\mathrm{Al}$ hydroxides to alumina, and alumina to Al metal via the Hall-Heroult process, $\mathrm{H}_{2}$ generation from the hydrolysis of $\mathrm{Al}$ is a niche application. Nevertheless, this $\mathrm{H}_{2}$ generation route has significant potential for on-site and on-demand energy vector generation. It is recommended that further research into developing up-scaled processes for $\mathrm{Al}$ composite fabrication, fit-for-purpose reactors, and real-world applications should be carried out in the future.

\section{Acknowledgment}

The Department of Science and Innovation (DSI), South Africa, and HySA Infrastructure Centre of Competence at the North-West University (NWU), South Africa, are acknowledged for financial support through the KP5 program.

\section{References}

1. Du Preez SP, Bessarabov DG (2017) Hydrogen generation by means of hydrolysis using activated Al-In-Bi-Sn composites for electrochemical energy applications. International Journal of Electrochemical Sciences 12: 8663-8682

2. Du Preez SP, Bessarabov DG (2017) Hydrogen generation of mechanochemically activated Al-Bi-In composites. International Journal of Hydrogen Energy 42(26): 16589-16602.

3. Du Preez SP, Bessarabov DG (2018) Hydrogen generation by the hydrolysis of mechanochemically activated aluminum-tin-indium composites in pure water. International Journal of Hydrogen Energy 43(46): 21398-21413.

4. Du Preez SP, Bessarabov DG (2019) The effects of bismuth and tin on the mechanochemical processing of aluminum-based composites for hydrogen generation purposes. International Journal of Hydrogen Energy 44(39): 21896-21912.

5. Bessarabov DG, Du Preez SP (2018) Activation compounds for hydrogen generation, Netherlands Patent, Netherlands.

6. Elitzur S, Rosenband V, Gany A (2015) Electric energy storage using aluminum and water for hydrogen production on-demand. International Journal of Applied Science and Technology 5(4): 112-121.

7. (2018) Army plans to license nanogalvanic aluminum powder discovery.

8. Osenar P, Sisco J, Reid C (2017) Advanced propulsion for small unmanned aerial vehicles: The role of fuel cell-based energy systems for commercial UAVs. Pp. 1-15. 